\title{
Assessing Financial Efficiency with Time-Driven Activity-Based Costing (TDABC) Model: Evidence from International Trading Companies
}

\author{
Francis Danomah \\ School of Economics, Shanghai University, China
}

\begin{abstract}
The allocation of indirect cost associated with a particular service in the most accurate way gives many different options. Understanding logistics process in terms of cost and profitability is a complex task, and there is need to more research in such bases. Traditional costing systems are not able to determine accurately the cost of different cost objects once based mainly on volume measures for costing allocation. With traditional cost systems giving inaccurate results as operations change, there is the need for organizations to implement modern costing annalistic models which can easily be integrated in cases of update on cost drivers or expenditure. In this paper, theories underlying Time-Driven Activity-Based Costing (TDABC) model have been used in a form of case study stimulation to examine how overhead cost can be properly allocated in organizational departments. The author attempts to implement the generic steps of the TDABC cost model as presented by Kaplan and Anderson in a case study to measure the financial efficiency of a logistics procumbent company based in china with clients mostly based in Africa.Traditional costing systems are not able to determine accurately the cost of different cost objects once based mainly on volume measures for costing allocation

Keywords: efficiency; TDABC; capacity costs; outsourcing; logistics procurement, international trade, Logistics Service providers, Fourth-party logistics service providers (4PL)
\end{abstract}

DOI: $10.7176 / \mathrm{JRDM} / 76-01$

Publication date:June $30^{\text {th }} 2021$

\section{Introduction}

The continuous development in world trade depends on the efficiency of trade support structures such as the logistics services. Despite logistics integral role in supporting commercial activities, there has generally been a low level of cost efficiency research focus on trade practitioners by scholars.

As global logistics trends continue to grow due to innovation, consumers have gained great attentiveness in door-to-door logistics services and other much convenient ways to procure goods. To minimize the cost of operations, most firms tend to outsource some part of the whole process to organizations or individuals who have specialized skills or resources to perform efficiently. The function gives most businesses the ability to focus on their core tasks rather than manage their total supply chain, thus, keeps them highly competitive within their markets. Usually, these outsourced functions become the core business for logistics service providers (LSP).

Over the decade, Logistics service providers have focused on improving their services with several innovative measures that can boost their output to meet the growing customer requirements. The main aim has typically been to provide services in the most efficient ways to win customers' satisfaction and loyalty in terms of cost and operations.

Major logistics operators in the industry such as third-party logistics service providers have achieved these objectives by the integrated operation of transport modes using their logistics assets. With such advantages, these operators have managed to master the flows of logistics processes along different supply chains, making them key players in today's industry.

Fourth-party logistics service providers (4PL) also known as Lead logistics service providers as their functions perceive, are non-asset-based operators. They act as managers of activities along the supplying chain. In a typical 4PL supply chain, the service provider serves as the single point of contact for both clients and forwarding partners. 4PLs mainly depend on strong cooperation with several 3PLs to successfully accomplish their goals. The ability to make good decisions when it comes to selecting a 3PL service provider to outsource is vital to the 4PL business concerning productivity.

Having no actual assets to assess tangible cost, managing overhead cost allocation in a startup company with 4PL functions might turn to be a bit complicated. With limited literature available on the allocation of logistics costing using analytical tools and models, this research focuses on how logistics cost can be properly allocated to the in-service industry. The cases studied are selected from an international organization that is involved in the sourcing of procurement functions for its clients. The major market for this company is West African small and medium-scale firms. 


\subsection{Outsourcing and third-party logistics (3PL)}

Generally, outsourcing, third-party logistics and contract logistics generally mean the same thing. The given definition of logistics outsourcing is quite similar to the one generally attributed to outsourcing. Ivanaj and Massou Franzil have defined the logistics outsourcing as "the fact to entrust the whole supply chain, previously internally ensured, or only a part of it, with an eventual transfer of resources, over a long-term period, to an external provider, with a performance aim". (Ivanaj Vera, 2006)

Mamdouh Tlaty and Mohamed Moutmihi stated in their research that the partnership with a logistics service provider is contractual. Therefore, a contract must be established between logistics service provider and the companies in need of the service. Companies could also set firms of different structures, to whom outsourced activities will be entrusted. (Moutmihi, Mamdouh Tlaty \& Mohamed, 2015)

\subsection{Drivers of outsourcing}

According to Rinsler 2014,the motives for outsourcing can be split into five different groups:

- Financial

- Technology

- Managerial

- Resource management

- Personal

The most significant financial element is flexibility of usage of resources. It can often be pooled with that of the others, which creates better scale and marginal costs. It also ensures some independance in managing those resources. another financial factor is accessibility to assets. it should be possible that the outsourcing partner can borrow at a stronger rate. this can be because the outsourcing company encompasses a lower risk through better focus. Sometimes these borrowing costs are well worth the flexibility. (Rinsler, 2014)

The flexibility of use of resources is additionally a crucial factor; if the company's use of the resources is often pooled with others, creating better scale and better marginal costs, then using an outsourcer ensures some independence of management of these resources and releases the company from having to manage the other users of the facilities. (Rinsler, 2014)

Technological factors in outsourcing have become more vital during the last two decades. This is because the growth of technology has become much faster and the pace keeps accelerating. Competitive edge comes from integrating companies with new technologies expeditiously. Companies must ration their resources so it's rather more reasonable to concentrate investments on the sales systems than the most recent technology. In the past, organizations and manufacturing companies used to take charge of maintenance of their machinery completely but with current technology, machines come along with "black boxes" that are replaced on failure, and the skills of the supplier used to renew them as they have the know-how, thus the maintenance skills are outsourced. (Rinsler, 2014)

Most organizations turn to outsource their IT systems and software management. Integrated systems have influenced most business to supplement their IT support staff with analysts and programmers, often through specialized consultancies to whom they delegate the resource provider to create the company's software and in other situations the whole IT systems which entail the data handling and software management are outsourced to these consultancies. (Rinsler, 2014)

The usual problem with forecasts is that they are seldom right. Focusing on core resource business areas can make it easier for management to forecast resource requirements. When considering periphery areas in a company's business, the forecasts are not always very exact. Outsourcing to a specialist can increase the likelihood of optimizing forecasts and therefore increase the amount of service. The businesses should also think about the areas they will make a true difference in. Management and training skills should therefore even be concentrated on those areas. However, management should notice that when outsourcing, the new important skill to develop is the skill of selecting your partners and managing them. Personal reasons do cause outsourcing. It is rare for managers to have altruistic motives when deciding to outsource business processes. Managers should remember that unless there are clear strategic reasons for a change to be made, the change should not be made at all. (Rinsler, 2014)

\subsection{The concept of logistics service providers (LSPs)}

Logistics activities cover the whole supply chain so that they become important in improving a supply chain's overall performance. The target of the logistics process is to merge and organize all activities involved in acquiring, converting, and distributing goods from raw materials to finished goods to the purchasers so as to attain customer service targets in an efficient cost-effective manner. (Zaryab Sheikh, 2014)

Logistics service providers (LSPs) are companies that always act as intermediaries that undertake the execution of logistics-related activities that have been customarily kept in-house. (Aristides Matopoulos, EleniMaria Papadopoulou, 2010) 
LSPs are a significant factor in the business success of companies engaged in trade activities at national and international levels. They play a vital role in achieving competitive advantages of business entities directly involved in the purchasing and supply of commodities in international trade. (Helga Pavlic Skender, Alen Host,Melisa Nuhanovic, 2016)

According to (Persson G., 2001), the market of LSPs may be a very dynamic one and has evolved over the decades, in a trial to follow customers' pace and fulfill their constantly changing expectations. As mentioned earlier, the competitive advantage of most businesses is based on the provision of differentiated, innovative, and quality services offered by LSPs, thus imposing significant pressure on them to continually evolve (Wang, 2006). Another factor that drives the evolution of LSPs is the ever-expanding scale and scope of operations, as a consequence of the increased international competition (Sohail S., 2004)

The activities of LSPs have seen several groundbreaking changes since their emergence in the late 1980s. Originating from maritime, road, rail, or freight forwarders or courier activities, the origin of logistics providers explains their diversity. To meet the increasingly demanding expectations of customers, the modern trend of service providers is to offer services that are as wide as possible, when originally these activities were particularly segmented (M. Michrafy \& T. Roques, 2003). For a few LSP, it could be a matter of tending towards total integration of the various logistical operations of the principal. The supply of LPSs is varied, ranging from the simple transport of goods to complex, customized, and measured solutions.

According to Fulconis (2011), three periodically verifiable waves of the logistics service have been distinguished: the first category emerged during the 1980s providing the basic services of transportation and warehousing; during the second wave around the 1990s, the service provider becomes a real expert to satisfy the client's request, on more or less complex logistics activities such as parcel and express services (Fulconis F, 2011). Finally, during the third wave, the service provider actively takes part in the co-definition of processes in a strategic vision of the company. It is even possible to mention that the LSP become in a later stage, codesigners or even designers and supply chain managers, innovatively and creative method.

In parallel to the evolution of the LSP industry and the above-mentioned changes, the sector has also witnessed changes with respect to the criteria used in the selection process.

Till this day, logistics services providers' activities keep evolving as technology and science keep turning things around. With logistics service providers (LSP) being the stakeholders in logistics outsourcing, the trend towards outsourcing logistics operations by manufacturers and trade companies makes these providers widely sought and recognized professionals. Inspired by a quest for cost efficiency, this orientation is nowadays similar to a need to acquire skills not internally available or difficult to preserve. The construction and execution of innovative value-creating offers for companies are, therefore, at the heart of the LSP strategies. (Bouchette, Achoui, Saki, \& Kabbaj, 2018)

\subsubsection{Lead time}

Generally, lead time is the time between order and delivery. Lead time can be defined as the number of minutes, hours or days that must be allowed for the completion of an operation or process must elapse before a desired action takes place. (Business dictionary, 2020)

The management of lead time can be a competitive advantage (Tersine, et al., 1995). Time-based competition refers to the ability to deliver products or services more efficiently than the competitors. Lead time minimization strategies are responses to logistical shortcomings in the areas of procurement, manufacturing and distribution. In particular, an assessment of lead times in distribution systems offers a wide range of opportunities for improvement. (Villarreal, 2008)

Time-based competition mandates a strategy of customer responsiveness and rapid new product introduction, together with competitive quality and cost. The essence of time-based competition involves compressing time in every phase of the product creation and delivery cycle. This translates into a significant source of competitive advantage. Increasingly, only time-based competitors will have the ability to dominate their industries. This is because customers have become sophisticated and sensitive to the magnitude of choice and the degree of responsiveness provided by businesses in both the manufacturing and the service sectors. Only time-based firms will be able to meet such customer demands and to respond quickly to changing consumers' needs. (Sim, 1994)

\section{Literature Review}

According to Reynolds, Fourie and Erasmus (2018) in a case study to devise a framework for South African SMEs with resource constraints, they adapted the generic steps for TDABC as described by Kaplan and Anderson (2003). They found that it was practical to implement TDABC at a manufacturing SME by extrapolating the cost data from a single product which harnesses all the key activities in the factory. The TDABC data were sufficient for analysis of unused capacity and over-expenditure, hence providing information to consider in profitability enhancement and to support the TOC. They concluded that the proposed framework for TDABC model implementation at SMEs revised the generic framework suggested in literature by focusing 
on key products only and consolidating activities. (Reynolds, Fourie, \& Erasmus, 2018)

Pernot, Roothooft and Van den Abbeele (2007) in a study about inter-library loan (ILL) acquisition and circulation, used of TDABC to assess inter-library loan (ILL) costs and described TDABC as a useful technique to scale back ILL resource costs and to renegotiate ILL service prices based on more precise costs. The authors concluded that TDABC is extremely appropriate to address increasing cost pressures, and its findings can contribute to improve library services at lesser costs. (Pernot, Roodhoft, \& Van den Abbeele, 2007)

In an attempt to solve a problem of third-party logistics industry cost information distortion and improve the level of logistics cost management, Heng Ma (2014) in a case study analysis of S Company combined theoretical research and case analysis method to reflect cost allocation by building third-party logistics costing model using Time-Driven Activity-Based Costing (TDABC). The study took S company as an example to account and control the warehousing logistics cost. It was concluded that, TDABC can accurately reflect the cost allocation of service customers and reveal the spare capacity cost of resource center, verifies the feasibility and validity of TDABC in third-party logistics industry cost accounting. (Ma, 2014)

Irena Pawlyszyn (2017) in a study assessed financial efficiency of a logistics electronic warehouse with the applications of TDABC methodology and Lean Management concept as a basis for undertaking lean activities. The author used the generic procedures of cost allocation calculation proposed TDABC method by Kaplan and Anderson. It was concluded that, the integration of TDABC model and the Lean Management enables the implementation of basic procedures towards the reduction of income wasting, identification of unused capacities, and detection of potential of the resources. (Pawłyszyn, 2017)

\section{3: Relationship between International trade and logistics services}

\subsection{The impact of logistics on international trade, world economy and COVID 19}

The trend of world trade and economy is undoubtfully dependent of logistics. According to Devlin (2005), the quality and efficiency of logistics services is important for international trade as a feeble logistics infrastructure, and operational processes can be a main obstruction to global trade integration (DEVLIN \& YEE, 2005). It is evident that the countries with high level of logistics infrastructure are dominant in world-class trading.

Generally, a value-added trade-related logistics, joined with a liberalized economic environment can escalate trade volume and economies of scale and range in distribution and production activities.

As noted in the discussion above, the global economic environment has seen a significant increase in the volume of goods traded over the last two decades.

Naturally the quantity of goods traded between two countries is largely influenced by the availability and the quality of logistics services, among other things, both in the exporter and importer countries. Effective logistics systems depend basically on good infrastructure and the availably of efficient logistics services providers. Thus, the activities of LSPs contribute to the macroeconomics of the nations and the world at a whole.

Currents global pandemic situations have highly affected the usual routings of all civilization around the globe. As other industries struggle with mass closures, logistics has been ramping up and revolutionizing. While the world wars against the raging health situation of the pandemic, the significance of good logistics systems and LPSs has been highlighted in most discussions. That has been easier said than done. The global pandemic has put a life-or-death pressure on the logistics industry, with need for mobile or temporal health centers, medical supplies within both urban and remote location, effective logistics services are required for life saving situation of patients. It's become increasingly clear that winning the war against COVID-19 will be a battle of logistics.

\subsection{Logistics procurement}

As organizations grow, new global customers present a lucrative target but there is a steep cost to servicing these customers. These customers expect high service level, high and fast logistics capabilities, and innovative products at a low price. Managers' top priorities identified are meeting customer expectations followed by ontime delivery, this has mounted cost pressure on old and upcoming companies, and it has driven many companies to capture the cost savings, and additional savings require more sophisticated approaches.

The era of moving supply to emerging countries to exploit low-cost labor is coming to an end, as the savings are not as easy to find as they were in the past few years. Now, organizations are noticing that they must begin to truly adopt analytical tools to design their logistics networks that capture multiple cost drivers.

Most successful companies work actively on becoming more competitive in one way or another (Landry, 2015). This can involve anything from market visibility, product development, logistics solutions, cost efficiencies and more.

To operate in the most efficient way, many companies are realizing that they cannot function independently. This has sparked the need for partnerships in a networked community where companies are codependent on each other. Many companies make the decision to outsource their logistics services logistics service providers (LSPs) as it can relieve a lot of their responsibilities.

For some regionally based firms and businesses enterprises such as wholesalers and retailers, most of their 
supplies are imported from factories or sellers around the world. The cost of obtaining these goods and the processes and technicalities involved may call for the need to outsource such functions to experts, such as logistics procurements who have vast resources when it comes the market of suppliers and manufacturers and sometimes location advantage.

\subsubsection{Relationship between outsourcing and logistics procurement}

Generally, Procurement is the act of obtaining goods or services, typically for business purposes. Procurement is most commonly associated with businesses because companies need to solicit services or purchase goods, usually on a relatively large scale. According to Young (2019) At its core, procurement logistics is the sourcing of materials needed to manufacture products. In other words, this part of the supply chain focuses on purchasing raw materials, replacement parts, auxiliary supplies, operating supplies and other items needed for the manufacturing process to work. (YOUNG, 2019).

Insights from Prologis Inc. (2020) show that Procurement logistics doesn't just deal with the purchasing of materials but however It also handles storing, organizing and shipping these materials to and from the warehouse. The procurement logistics team is responsible for product sourcing and selection policies, terms and conditions, communication and purchasing strategies to help keep the cost of acquisition as low as possible. (Prologis Inc., 2020)

Outsourcing procurement is often undertaken by very large companies to save money. Procurement requires a great deal of focus on cost-saving, profit maximization and compliance. Often good procurement strategies can be the difference between a profitable company and a failed business. Some companies such as Amazon, Tesco and Walmart have made their purchasing strategies a competitive advantage. Procurement can be very complex and cost consuming in many large companies so some of them are outsourcing procurement rather than build their own world-class procurement capabilities. (Outsourcing Procurement - Benefits vs Problems, 2020)

A procurement outsourcer can leverage their economies of scale and have the experience and trained staff that cut costs and enhance efficiencies. Smaller companies that have experienced growth spurts and have few internal purchasing resources are also outsourcing procurement to take advantage of external structures and expertise. Others that do not have the market leverage to obtain good discounts or the expertise to find good suppliers or purchasing staff are also turning to outsourcing procurement.

By outsourcing procurement companies are able to concentrate on their core capabilities, confident that their purchasing is being effectively and profitably managed. Many large companies have ensured that they have "first movers' advantage" by concentrating on their core business as opposed to purchasing.

\subsubsection{Costing in logistics procurement companies}

Due to the amount of transparency of processes and procedures involved in engaging in logistics procurements functions, costing and cost allocation is very imperative for LSPs. Along the several tasks and processes involved in providing service to customers at the least cost price per service offered, logistics managers seek to find which best ways work efficiently, cut down cost and maximize profits in their operations.

Previously, traditional cost calculation also known as the conventional method performs the allocation of overhead to outputs based on the volume of resources consumed per total output (such as machine hours, labor hours etc.). When the overhead comprises only a fraction of an output's costs, the conventional method has little effect on the accuracy of the output cost. (Tsai, 2018)

Although some traditional costing systems provide detailed reports, they may not be effective and do not reflect the activities and processes that define the organization. (Johnson, H.T., \& Kaplan, R.S., 1993)

In many companies the costs vary considerably according to the diversity of the product and/or the complexity of operations, therefore there is a need for more elaborate and dynamic costing systems. Such necessity is due to the fact that the information provided by traditional costing systems is not complete or sufficiently credible for managers to make good decisions for both strategic and operational purposes (Gunasekaran, A., \& Sarhadi, M., 1998).

In this sense, Johnson and Kaplan (1993) developed the Activity-based costing (ABC) model to circumvent the cost allocation problems associated with traditional costing, using a more detailed analysis of the relationship between overhead costs and cost drivers.

\subsection{The concept of Fourth-Party Logistics (4PL) or Lead Logistics Provider (LLP)}

The Council of Supply Chain Management Professionals (CSCMP) defined by 4PL or LLP as an organization that organizes other third-party logistics partners for outsourcing of logistics functions. An LLP serves as the client's primary supply chain management provider, defining processes and managing the provision and integration of logistics services through its own organization and those of its subcontractors. (CSCMP, 2013). A 4PL or LLP has also been defined as a firm that specializes in the various functions of the supply chain and has cross-skilled teams to effectively lead, manage, and control the supply chain roles of various clients. It can be a huge multinational 3PL who incorporates a special LLP business unit which caters to the 4PL needs of the 
clients; or it could be a non-asset owning organization that has skilled resources in the various sub-functions of supply chain. (Supply Chain Science, 2016)

By engaging a 4PL supplier, a company is effectively outsourcing the logistics aspect of its operations, to an independent specialist contractor/consultant, whose core business is in this particular field. This will enable a company to reduce its overhead costs since it will no longer require a logistics or planning department, and it will be able to concentrate on its business strategy. (Sure Destiny , 2018)

A Third-Party Logistics Provider (3PL) is a firm that provides multiple logistics services for use by customers. Preferably, these services are integrated, or "bundled" together by the provider. These firms facilitate the movement of parts and materials from suppliers to manufacturers and finished products from manufacturers to distributors and retailers. Among the services which they provide are transportation, warehousing, crossdocking, inventory management, packaging, and freight forwarding. (Supply Chain Science, 2016)

As firms such as SMEs and other forms of companies look to focus on core competencies, they seek for a good partner to manage their supply chains. There are big and small players who provide services in the 4PL or the LLP market segment. There are many big and established players like DHL Supply Chain, K+N, DB Schenker, Ceva Logistics, etc. each providing a value addition and array of capabilities to manage the supply chains of the biggest companies of the world.

Comparing the definitions of 4PL and 3PL, the difference between a Third-Party Logistics (3PL) provider and a Fourth-Party Logistics (4PL) provider, is that a 3PL service only provides for executing a part of an overall supply chain process, whereas a 4PL service provides for executing the complete supply chain process, from start to finish, for the customer. Table 1 shows some differences between 4PL and 3PL:

Table 1: Fourth-Party Logistics vs. Third-Party Logistics Fourth-Party Logistics Provider (4PL)

- Non-asset based.

- Focused on Optimizing supply chain.

- The single point of contact for full supply chain.

- Manages the whole process, sometimes even the 3PL.

- Specialize in the operational elements of supply chain management.

- All aspects (ideally) of the client's supply chain are managed by the 4PL organization.

- It is possible for a major third-party logistics provider to form a 4PL organization within its existing structure. Third-Party Logistics Provider (3PL)

- Asset-based (often times own warehousing transportation assets).

- Focused on Day-To-Day operations.

- One of two points of contact in supply chain.

- Targets a single function.

- Manages the activities of supply chain.

Source: the author's summary

\subsection{Methodology: Time-Driven Activity-Based Costing (TDABC) model in concept}

Cost management has been evolving from a traditional approach, mainly focused on operating cost allocation and product costing to a most complete analysis of organization's cost structure, value analysis and strategic cost management. Activity-Based Costing (ABC) systems and more recently Time-Driven Activity-Based Costing (TDABC) systems are especially important in this context. Activity-Based Costing is a costing method that measures costs and the performance of activities and cost objects. It is based on the three following assumptions: products require activities: activities consume resources and resources cost money. It emphasizes that activities consume resources and, that products consume activities. ABCM models evolved from the initial $\mathrm{ABC}$ to the more recent TDABC which is supported on time equations. (Paulo Afonso, 2016)

Thus, traditional costing methods have been substituted by activity-based cost management (ABCM) approaches which rely on the full (absorption) costing principle. Nevertheless, these approaches explain and reflect much better the production flow and the production conditions and restrictions through the use of more cost centers and better cost drivers. (Cooper \& Kaplan, 1998)

Accordingly, Kaplan and Anderson $(2004,2007)$ developed the TDABC, a more "transparent methodology, scalable, easy to implement and update", which allows managers to obtain important information about costs and profitability, quickly and inexpensively. TDABC is presented as a simpler and more affordable system than the traditional $\mathrm{ABC}$ approach, simplifying the costing process and eliminating the need of surveys and interviews as required in an ABC. (Kaplan \& Anderson, 2007) TDABC was created to address the difficulties faced by the implementation of $\mathrm{ABC}$ models and uses duration drivers instead of transaction drivers which can be easily revised when conditions change. (Everaert, P., Bruggeman, W., Sarens, G., Anderson, S. R., \& Levant, Y., 2007,2010)

A time-driven costing process automatically reveals any differences between the total time needed to carry out all of the activities performed by a department, and the total amount of time the department's employees 
have available. This makes time-driven $\mathrm{ABC}$ a more rigorous methodology for $\mathrm{ABC}$ programs in which better capacity management is an objective. (Barrett, 2005)

There are numerous case studies on the application of the TDABC, where it is possible to note its advantages, namely that it is a model of easy design and integration with software (Pernot E. R., 2007). Through TDABC, it is possible to study the effectiveness of the procedures in terms of available capacity versus used capacity. Thus, including other advantages, TDABC permits to assess the added value that determines the existence of each activity, simulate the use of resources, etc. But also, limitations were noted in some case studies in which, for example, there was the fact that it can be required a huge amount of data for estimating time equations (Everaert, P., Bruggeman, W., Sarens, G., Anderson, S. R., \& Levant, Y., 2007,2010)

TDABC is supported on two key parameters, the cost per time unit of capacity and the time required to complete an activity - time is typically considered the measure of the capacity ( (Kaplan \& Anderson, 2007). It is a model that assigns resource costs directly to cost objects. Thus, it first calculates the costs of all resources (equipment, personnel, etc.) and, subsequently, divides them by the capacity, which is the time for the execution of the work, effectively used.

Secondly, the model distributes the resource costs using the capacity cost rate and the conditions and resource requirements for each cost object (Everaert, P., Bruggeman, W., Sarens, G., Anderson, S. R., \& Levant, Y., 2007,2010). When the model is used to allocate cost to a cost object, it is treated as a constant value. For an illustration of the mathematical relationship, see figure 1.

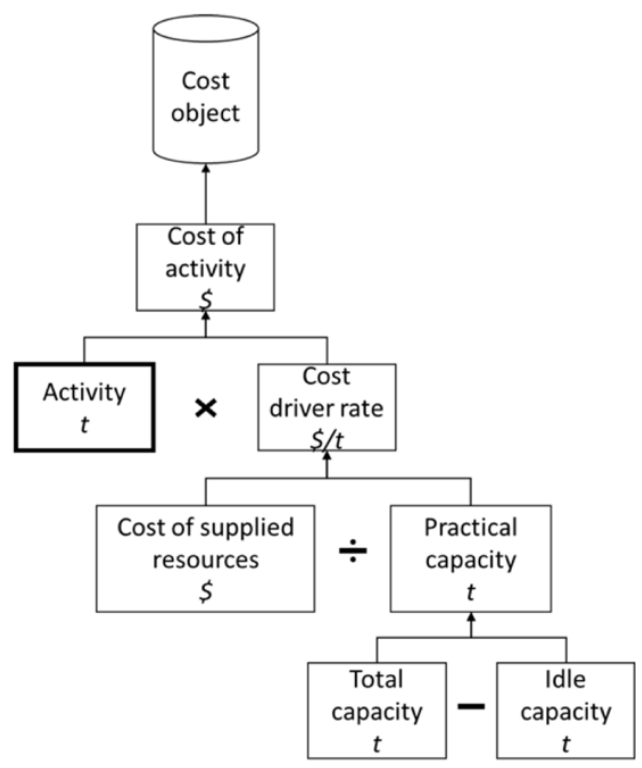

Figure 1: TDABC input parameters based on Kaplan and Anderson, 2004,

Source: Author's summarization

A TDABC system is presented in the form of time equations which reflect the costs of different cost objects taking into account the particularities of consumption of each activity by each particular product, assuming a standard time of execution of the activity plus an incremental time to perform additional activities. Thus, it is a model that assigns resource costs directly to cost objects. ( (Homburg, 2005; Kaplan \& Anderson, 2007)

According to Gervais (2010), TDABC uses standard data as a starting point as well as a basis for the calculations, which reduces the amount of data to be collected (Gervais, M., Levant, Y., \& Ducrocq, C., 2010).

Mathematically, the TDABC can be explained as follows, using time (Everaert, P., Bruggeman, W., Sarens, G., Anderson, S. R., \& Levant, Y., 2007,2010). In a time, equation, the time consumed by the event in the activity can be expressed as a function of different characteristics called time drivers. The general time equation needed by the event $\mathrm{E}$ of the activity $\mathrm{A}$ with $\mathrm{p}$ of possibility is given by: 


$$
t_{E, A}=\beta_{0}+\beta_{1} * X_{1}+\beta_{2} * X_{2}+\beta_{3} * X_{3}+\beta_{P} * X_{P}
$$

$T_{E, A}-$ Time required for executing the event $E$ in terms of activity $A$

$\beta_{0}-$ constant amount of time for activity $A$

$\beta_{1}$ - time consumed per unit of time driver 1

$X_{1}$ - time driver 1

$X_{p}$ - time driver $p$

$p-$ number of drivers needed to run the activity $A$

\section{Figure 2: TDABC time equation}

Source: (Paulo Afonso, 2016)

Transforming an $\mathrm{ABC}$ model in a TDABC can be a fairly simple process. The relationships between resource cost pools, activities and cost objects identified in an ABC model can be adopted in a TDABC based model via 'resource groups' (e.g., support staff, facilities, administration) and using multiple time-based drivers to allocate costs to cost objects or eventually, using a single time-based driver if there are complexities in the collection of the data.

The understanding of the logistics process in terms of costs and profitability is a complex task, and there is a need for more research and applied for work on these issues. In this paper, the generic concepts of TimeDriven Activity-Based Costing (TDABC) were used in the context of logistics sourcing costing.in an international trade situation.

In a case study, results and implications cannot be directly or immediately generalized. Nevertheless, the proposed time equations and cost model can be easily adapted to explain other types of logistics functions and the procedures implemented in the research serves as the foundations to other TDABC models with more than one capacity cost rate. The TDABC model used in the study can be used in similar cases, and as a basis for the analysis of logistics costs in other logistics processes. Furthermore, managers can rely on the proposed approach to analyze profitability and logistics cost structure.

\subsection{Development of Case Study}

\subsubsection{Background of KN Logistics Company Ltd.}

As the strength of economic power in concerned globally, China has been undoubtedly the hub of manufacturing. Most businesses around the world that are into bulk buying of goods turn to look to Chinese factories when it comes to supplies of inventory due to several economic advantageous factors.

African countries are no exceptions when it comes to the high consumption of made-in-China products. For the past years, many African business entities have trooped into China to seek for factories where they could produce specific goods to provide for their customers who could be other business entities.

The cost of traveling each time, the time spent in doing prospection and the stress involved in such a business style caused the need for middlemen who could visit factories on behalf of their clients for prospections of products and take care of the total shipment until the goods leave China. Most African and other foreigners living China were involved in these agreements with buyers from African countries and some other became partnerships that have birthed young organizations, such as the studied company for this research.

$\mathrm{KN}$ logistics is a startup Logistics Company founded on the bases of middleman agreements between the company owners and several clients within the African region. Being in existence for 5 years, the company has grown to integrate logistics function with procurement.

Currently the company has 5 departments, two international offices and 10 full time employees is into international outsourcing of purchases of material and goods of any kind with another function of total shipment processes responsibilities for clients. To work in the most efficient way, the company assumes lead logistics functions by controlling their own supply chain with no own assets. The core business of the company is centered on its ability to give it clients the most cost-effective services with high transparency of which provides the company lots of devoted customers.

Even though the company isn't currently operating at losses, some inefficiency in cost allocation occurs particularly in terms of allocating service charges to customers. The management seeks to explore more accurate 
ways in charging customers instead of using their base charge together with special charges per type of service required. The company uses the conventional method in allocating overhead cost by splitting the total expenditure among its departments equally.

After several accounting periods, the company has come to a realization that there is a usual issue of some expenses surfacing that cannot be directly related either cost of operation nor customer related costs. Assumptions show some costs should be added to customer fees instead of just overestimating cost per department, which seems to be inaccurate pertaining the activities and responses from employees during expenditure meeting.

In conclusion it can be summarized that the company faces the following problems:

i. The cost assigned to customers isn't accurate

ii. Unseen costs surfacing during total expenditure calculation

iii. Misidentification of orders or activities which consumes resources or capacity.

iv. Wrongful assumptions of equal resource utility among all departments.

\subsection{Case Analysis: Cost Allocation with TDABC Analysis}

The overhead cost used in the TDABC model design application was obtained from the company's financial records. This was the total overhead cost per department of the company over a quarter of the accounting year; the amount was obtained using the conventional cost allocation method.

To design and incorporate the new model for the cost allocation analysis, one department was sampled. This was the operations department, which had 4 employees in full time roll. This study attempts to be finding out whether the overhead cost estimated for these departments actually coincides with the real capacity consumed within the department. The successful design of the TDABC annalistic tool could help the company in appropriate cost allocation of its total expenditure according to activities' performance at departmental levels.

For TDABC model results to be accurate there are few factors to be considered. The model operates on several time equations. The cost of resources, which is known to be the cost per capacity, and the time required to complete an activity is crucial for results accuracy. The information from gathered data was computed using Microsoft Excel, to build a TDABC model to allocate the overhead cost per outputs produced. The model directly shows the link between cost and output at given capacity per time.

The analysis was done over a quarterly accounting period, which is 60 working days and 1920 working works per employee. Table 2 shows the step-by-step design and computation of TDABC model in KN Logistics Company Ltd.'s operations department.

Table 2: Total expenditure per-quarterly of the company

\begin{tabular}{|c|c|c|}
\hline \multicolumn{2}{|c|}{ Expenditure's Calculation of KN Logistics } \\
\hline Variables & Quantity & Cost per Quarter (USD) \\
\hline Offices Space Rent & 2 & $6,890.00$ \\
\hline Employees' Wages & 10 & $26,250.00$ \\
\hline Legal Firm Outsourcing & - & $18,000.00$ \\
\hline Miscellaneous & - & $8,000.00$ \\
\hline \multicolumn{2}{|c|}{ TOTAL } & $\mathbf{5 9 , 3 9 0 . 0 0}$ \\
\hline
\end{tabular}

Table 2 shows the total expenditure of the company, with two office spaces costing 6,890USD per quarter, the sum of wages of 10 full time employees (the total wage is the result of the suggested average wage per employee), the cost of outsourcing legal affairs to a local law firm; and miscellaneous showing all the little expenditures such as the cost of cleaners, coffee, etc. used in the in running the company. Using the old method of the company, each department cost was 11,878 USD per quarterly.

\subsection{TDABC application procedure}

In order to successfully design and implement the TDABC model for the operations department of the company, the researcher first considers following objectives. NB: all costs were calculated in USD. The following steps were established according to the TDABC model generic procedures proposed by Kaplan and Anderson (2004). The computations were all done using excel spreadsheet. The steps followed are presented below:

1. Identification of the activities are performed by the operations department

2. Number of employees in the department

3. Average time spent on each activity according to the employee survey.

4. Estimation of cost drivers each activity.

5. Calculated assigned cost per activity using traditional $\mathrm{ABC}$ method.

6. Calculate the cost driver rate. 
7. Time taken per activity (time used to per output).

8. Calculate cost per activity.

9. Calculated the allocated cost.

Table 3: Calculating the cost driver rate

\begin{tabular}{|c|c|c|}
\hline Activity & Estimated Cost Driver Quantity & Time (in Percentage) \\
\hline Searching for Product/Factory & 3700 Orders & $26 \%$ \\
\hline Procurement & 2400 Purchases & $10 \%$ \\
\hline Factory Visits \& Quality Control & 208 Hours & $64 \%$ \\
\hline
\end{tabular}

Table 3 shows the activities performed in the operations department, and the total percentage of time estimated to be used in doing those activities. The estimated cost driver quantity refers to the amount of output per activity over total allotted time period. For instance, '3700 customer orders' was successfully achieved concerning the 'Searching for product/Factory' activity. A total time period of 1,920 working hours per quarterly within the department. The time percentage shows the time consumed per each activity performed in the department. Data was from an employee survey.

Table 4: Number of employee and working hours

\begin{tabular}{|c|c|c|c|}
\hline Number of Workers & Hours per Week & Hours per Quarter (12 Weeks) & Cost per Hour (USD) \\
\hline 4 & 40 & 1920 & 6.19 \\
\hline
\end{tabular}

Table 4 shows the number of workers and their working hours. The time period for the research was per quarterly, which were 12 working weeks broken down into 8 hours in a day, 5 days in a week. Mathematically represented as:

Number of workers x Numbers of working hours per week x 12 weeks $4 \times 40 \times 12=1,920$ hours per quarterly.

The cost per hour of USD 6.19 was arrived by dividing the departmental overhead by the total number of hours; USD $11,878 \div 1,920$ hours $=$ USD 6.19

Table 5: Assigned cost per activity calculation

\begin{tabular}{|c|c|c|c|}
\hline Activity & Estimated Cost Driver Quantity & Assigned Cost (USD) & Time (in Percentage) \\
\hline Searching for Product/Factory & 3700 Orders & $3,088.28$ & $26 \%$ \\
\hline Procurement & 2400 Purchases & $1,187.80$ & $10 \%$ \\
\hline Factory Visits \& Quality Control & 208 Hours & $7,601.92$ & $64 \%$ \\
\hline Miscellaneous & - & $2,000.00$ & - \\
\hline Total Cost of Department & - & $\mathbf{1 1 , 8 7 8 . 0 0}$ & - \\
\hline
\end{tabular}

Table 5 shows how the assigned cost per activity was calculated. This was done by multiplying the total departmental cost by the time percentage per activity, i.e.,

USD $11,878 \div 26 \%=$ USD $3,088.28 U S D 11,878 \div 26 \%=U S D 3,088.28$

Given that USD $3,088.28$ of the total overhead was used for corresponding activity 'Searching for product/Factory'

Table 6: Calculating the cost driver rate

\begin{tabular}{|c|c|c|c|c|}
\hline Activity & Estimated Cost Driver Quantity & Assigned Cost (USD) & Time (in Percentage) & Cost Driver Rate (USD) \\
\hline Searching for Product/Factory & 3700 Orders & $3,088.28$ & $26 \%$ & 0.83 \\
\hline Procurement & 2400 Purchases & $1,187.80$ & $10 \%$ & 0.49 \\
\hline Factory Visits \& Quality Control & 208 Hours & $7,601.92$ & $64 \%$ & 36.55 \\
\hline Miscellaneous & - & $2,000.00$ & - & - \\
\hline Total Cost of Department & - & $\mathbf{1 1 , 8 7 8 . 0 0}$ & - & - \\
\hline
\end{tabular}

Table 6 shows the method of calculating the cost driver rate. To do this, the assigned cost per each activity is dived by output per activity that is the estimated cost driver per quantity, which is the result of the cost allocated for each output for activity. This can be represented for instance with activity 'Searching for product/Factory $=3700$ orders $\div$ USD 3,088.28= USD 0.83. It displays how much exactly the department spent per customer order. 
Table 7: Time taken per activity (per hour)

\begin{tabular}{|c|c|c|c|c|c|}
\hline Activity & $\begin{array}{c}\text { Estimated Cost } \\
\text { Driver Quantity }\end{array}$ & $\begin{array}{c}\text { Assigned Cost } \\
\text { (USD) }\end{array}$ & Time (in Percentage) & $\begin{array}{c}\text { Cost Driver Rate } \\
\text { (USD) }\end{array}$ & $\begin{array}{c}\text { Time per Activity } \\
\text { (in Hours) }\end{array}$ \\
\hline $\begin{array}{c}\text { Searching for } \\
\text { Product/Factory }\end{array}$ & 3700 Orders & $3,088.28$ & $26 \%$ & 0.83 & 1.20 \\
\hline Procurement & 2400 Purchases & $1,187.80$ & $10 \%$ & 0.49 & 0.50 \\
\hline $\begin{array}{c}\text { Factory Visits \& } \\
\text { Quality Control }\end{array}$ & 208 Hours & $7,601.92$ & $64 \%$ & 36.55 & 1.80 \\
\hline Miscellaneous & - & $2,000.00$ & - & - & - \\
\hline $\begin{array}{c}\text { Total Cost of } \\
\text { Department }\end{array}$ & - & $11,878.00$ & - & - & - \\
\hline
\end{tabular}

Data collected from employee survey showed the approximate amount of time in hours required to perform activities. This is represented on the table by 'Time per Activity'. This is shown in Table 7 above.

Table 8: Calculating cost per capacity

\begin{tabular}{|c|c|c|c|c|c|c|}
\hline Activity & $\begin{array}{c}\text { Estimated Cost } \\
\text { Driver Quantity }\end{array}$ & Assigned Cost (USD) & $\begin{array}{c}\text { Time (in } \\
\text { Percentage) }\end{array}$ & $\begin{array}{c}\text { Cost Driver Rate } \\
\text { (USD) }\end{array}$ & $\begin{array}{c}\text { Time per Activity } \\
\text { (in Hours) }\end{array}$ & $\begin{array}{c}\text { Cost per Activity } \\
\text { (USD) }\end{array}$ \\
\hline $\begin{array}{c}\text { Searching for } \\
\text { Product/Factory }\end{array}$ & 3700 Orders & $3,088.28$ & $16 \%$ & 0.51 & 7.20 \\
\hline Procurement & 2400 Purchases & $1,187.80$ & $8 \%$ & 0.40 & 0.50 \\
\hline $\begin{array}{c}\text { Factory Visits \& } \\
\text { Quality Control }\end{array}$ & 208 Hours & $7,601.92$ & $24 \%$ & 13.71 & 1.80 \\
\hline $\begin{array}{c}\text { Miscellaneous } \\
\text { Total Cost of } \\
\text { Department }\end{array}$ & - & $2,000.00$ & - & - & - \\
\hline
\end{tabular}

\begin{tabular}{|c|c|c|c|}
\hline Number of Workers & Hours per Week & $\begin{array}{c}\text { Hours per Quarter } \\
(\mathbf{1 2} \text { Weeks) }\end{array}$ & Cost per Hour (USD) \\
\hline 4 & 40 & 1920 & 6.19 \\
\hline
\end{tabular}

Table 8 shows how cost per activity was calculated. To deduce the results, the time taken per activity was multiplied by the cost per hour. For example, searching for factories

$=$ USD $6.19 \times 1.2=$ USD 7.428

Table 9: Calculation allocated cost with estimated cost per driver

\begin{tabular}{|c|c|c|c|c|c|c|c|}
\hline Activity & $\begin{array}{l}\text { Estimated Cost } \\
\text { Driver Quantity }\end{array}$ & $\begin{array}{l}\text { Assigned Cost } \\
\text { (USD) }\end{array}$ & $\begin{array}{l}\text { Time (in } \\
\text { Percentage) }\end{array}$ & $\begin{array}{l}\text { Cost Driver Rate } \\
\text { (USD) }\end{array}$ & $\begin{array}{c}\text { Time per Activity } \\
\text { (in Hours) }\end{array}$ & $\begin{array}{l}\text { Cost per Activity } \\
\text { (USD) }\end{array}$ & $\begin{array}{l}\text { Allocated Cost } \\
\text { (USD) }\end{array}$ \\
\hline $\begin{array}{l}\text { Searching for } \\
\text { Product/Factory }\end{array}$ & 3700 Orders & $3,088.28$ & $26 \%$ & 0.83 & 1.20 & 7.42 & $2,746.79$ \\
\hline Procurement & 2400 Purchases & $1,187.80$ & $10 \%$ & 0.49 & 0.50 & 3.09 & 742.38 \\
\hline $\begin{array}{l}\text { Factory Visits \& } \\
\text { Quality Control }\end{array}$ & 208 Hours & $7,601.92$ & $64 \%$ & 36.55 & 1.80 & 11.14 & $2,316.21$ \\
\hline Miscellaneous & - & $2,000.00$ & - & - & - & & \\
\hline $\begin{array}{l}\text { Total Cost of } \\
\text { Department }\end{array}$ & - & $11,878.00$ & - & - & - & 21.65 & $5,805.38$ \\
\hline
\end{tabular}

Table 9 shows the final stage pertaining to the implementation of the generic procedures of TDABC model. In order to allocate all costs per activities, the estimated cost drivers (outputs per unit of activities performed) were multiplied by the cost per activity. Still using the first activity for illustration, 3700 orders $\mathrm{x}$ USD $7.42=$ USD 2746.79. This shows that USD 2,746.79 was spent in searching for 3700 customer ordered products.

Now, considering the assigned overhead of the operations department being USD 11,878 as per quarterly period which was attain through conventional costing, only USD 5,805.38 has been accurately calculated for with the TDABC model, which leaves the room of about $52 \%$ unused capacity with the department allocated expenditure. 
Table 10: Cost of unused capacity and under-utilized hours

\begin{tabular}{|c|c|c|c|c|c|c|c|}
\hline \multicolumn{8}{|c|}{ Pre-Quarterly Cost Analysis for Operational Department Using TDABC } \\
\hline Activity & $\begin{array}{l}\text { Estimated Cost } \\
\text { Driver Quantity }\end{array}$ & $\begin{array}{l}\text { Assigned Cost } \\
\text { (USD) }\end{array}$ & Time (in Percentage) & $\begin{array}{l}\text { Cost Driver Rate } \\
\text { (USD) }\end{array}$ & $\begin{array}{l}\text { Time per Activity } \\
\text { (in Hours) }\end{array}$ & $\begin{array}{l}\text { Cost per Activity } \\
\text { (USD) }\end{array}$ & $\begin{array}{l}\text { Allocated Cost } \\
\text { (USD) }\end{array}$ \\
\hline $\begin{array}{l}\text { Searching for } \\
\text { Product/Factory }\end{array}$ & 3700 Orders & $3,088.28$ & $26 \%$ & 0.83 & 1.20 & 7.42 & $2,746.79$ \\
\hline Procurement & 2400 Purchases & $1,187.80$ & $10 \%$ & 0.49 & 0.50 & 3.09 & 742.38 \\
\hline $\begin{array}{l}\text { Factory Visits \& } \\
\text { Quality Control }\end{array}$ & 208 Hours & $7,601.92$ & $64 \%$ & 36.55 & 1.80 & 11.14 & $2,316.21$ \\
\hline Miscellaneous & - & $2,000.00$ & - & - & - & & \\
\hline $\begin{array}{l}\text { Total Cost of } \\
\text { Department }\end{array}$ & - & $11,878.00$ & - & - & - & 21.65 & $5,805.38$ \\
\hline $\begin{array}{l}\text { Cost of Unused } \\
\text { Capacity }\end{array}$ & - & $6,072.63$ & - & - & - & - & - \\
\hline $\begin{array}{l}\text { Under Utilized } \\
\text { Hours }\end{array}$ & - & 296.95 & - & - & - & - & - \\
\hline
\end{tabular}

\begin{tabular}{|c|c|c|c|}
\hline Number of Workers & Hours per Week & $\begin{array}{c}\text { Hours per Quarter } \\
\text { (12 Weeks) }\end{array}$ & Cost per Hour (USD) \\
\hline 4 & 40 & 1920 & 6.19 \\
\hline
\end{tabular}

In calculating unused capacity, the total of the allocated cost per cost driver was deducted total expenditure of the department. That is USD 11,878 - USD 5,805.37 = USD 6,072.53, which shows that more than half of the department's capacity is underutilized. It also shows 296.95 hours out of the total of 1,920 hours.

\section{0: Empirical Findings}

This chapter presents the summary of data analysis results, findings, conclusions and future research recommendations.

\subsection{TDABC Model Results}

The author followed the general steps of TDABC model implementations as proposed by the Kaplan and Anderson (2004) and was able to successfully implement the model on the selected cost allocation problem from the studied company.

The result from the data analysis shows that there were underutilizations of the department's capacity summing to USD 6,072.53 and also there was a situation of unused time of 296.95 hours.

The outcome of the model computation highlighted the slack in method at which overhead is assigned to the departments within the company. Even though, the processes performed within Operations department of KN Logistics Company Ltd. could be vital to the company's general profitably and their activities may seem to consume a great deal of company's resource, it's been evidently proven that only $48 \%$ of the assigned overhead can be traced directly to activities performed by the department's staff. The management of the company with these results can further examine other departments as it's highly probable that overhead is being over estimated. Management of the company with this evidence can know which costs should be corresponded to customer service charges as well.

\subsection{Summary and findings from Case Study}

Results: In the case study, basic Time-Driven Activity-Based Costing (TDABC) model was implemented using nearly accurate figures for the operations department of the studied company. The results of the model depicted several outcomes in the real situation of the studied company. The first instance was the overhead cost allocated to the operations department could actually be higher than the real departmental expenditure. The second outcome could be that the operations department actually did not make fully utilization of the allocated resources.

With the given situations, the company can allocate cost per servicer provided to their customers which can aid them in proper calculation for service charges. Now, the company may apply this model to the rest of their departments to know which departments actually incomes the highest operations cost.

Discussion: These outcomes show that generalizing cost factors in companies or to departments isn't usually accurate as the cost per activities performed in a company can hardly be guessed out. Using accurate model analysis could help companies realize the amount of capacity unused or under unutilized hours.

\subsection{Conclusion and recommendations}

Over the period, innovation in transport and Logistics has undoubtedly increased the growth rate of international trade and affected the world economy in a positive manner. Countries with good logistics infrastructure 
nowadays are on top of several supply chain of many goods.

The ability of a business to thrive depends on appropriate allocation of resources and proper management of finances. Thus, implementing good analytical methods in logistics service costing and total overhead allocation are important for both macro and micro LSPs within the industry.

Thus, the results of the TDABC model on assessing the cost efficiency of the Operations department of the studied company, KN Logistics Company Ltd. portrayed two outcomes in the real situation. The first instance is the overhead allocated to the operations department may actually be higher than its real expenditure. The second outcome can be that their operations department actually unused the allocated resources. For the unused hours of 297 is can be said those were idle or break time for the employee as about $85 \%$ of their work hours were properly used.

With the verified analysis based on the model, the company can now assign cost to customers per service provided instead their old method of costing with "a base charge together with special charges per type of service required" method.

Now, the company may apply this model to the rest of their departments to know which one actually income the highest operations cost.

Secondly it can be concluded that logistics operations in the West African concept is still below the "normal standards" in comparison to the West. Due to the existence of poor logistics infrastructure, choosing a trusted logistics provider mostly isn't too considerate on the cheapest or most affordable choices but also factors as safety of cargo. Also considering the nature legal liabilities related to international trade, choosing a particular freight forwarder to delivery at named locations of customers will go a long way to reduce disputes in case problems are incurred during the shipment of consignments.

This paper presents the time equations designed for the case, the cost of the relevant cost objects, the cost of unused capacity and an analysis of the margins. The TDABC model developed in this case study can be used as a basis for the design of more robust logistics cost models and it can be applied in other similar cases.

TDABC model can be implemented in several ways. The model structure is very dynamic and can adjust to any form of changes. For example, the model design is built; costing amounts, times used for and all other figures with model can be change. When figures change within the model, it automatically updates. New activities can always be added to the model.

The focus of this study was to assess financial efficiency of logistics service providers using the generic method proposed by Kaplan and Anderson. Even though TDBAC is more accurate and currently data need to be usually put after activities and done over a time period. What has been noted through the study is there allocated timing of activities might not be equally accurate as it's by word of mouth from employees. As the generic model serves, a basis to more complex TDABC model with more than capacity cost rate, future research may focus on the use of TDABCD model with real-time situations to assess efficiency of logistics service providers. A suggested topic for future research is: Assessment of the efficiency of a perishable good production unit with TDABC model on proposed real-time Bases.

\section{References}

Outsourcing Procurement - Benefits vs Problems. (2020). Retrieved from Purchasing ad procurement center: https://www.purchasing-procurement-center.com/outsourcing-procurement.html

Aristides Matopoulos, Eleni-Maria Papadopoulou. (2010). The Evolution of Logistics Service Providers and the Role of Internet-based Applications in Facilitating Global Operations. In S. L. Lihui Wang, Enterprise Networks and Logistics for Agile Manufacturing (pp. .297-310). London: Springer.

Barrett, R. (2005). Time-driven costing: the bottom line on the new ABC. Business Performance Management, 35-39.

Bouchette, H., Achoui, M., Saki, Z., \& Kabbaj, S. (2018). Analysis of the Logistics Service Provider/principal relationship: In the light of innovation as a LSP strategy. 6th International OFEL Conference on Governance, Management and Entrepreneurship New Business Models and Institutional Entrepreneurs: Leading Disruptive Change (p. 20). Dubrovnik: http://www.econstor.eu/.

Business dictionary. (2020, October 31). Retrieved march 06, 2018, from http://www.businessdictionary.com/definition/lead-time.html

Cooper, R., \& Kaplan, R. S. (1998). Measure Costs Right : Make the Right Decisions. Harvard Business Review, 96-103.

CSCMP. (2013, August). CSCMP Supply Chain Management Definitions and Glossary. Retrieved from CSCMP: https://cscmp.org/CSCMP/Educate/SCM_Definitions_and_Glossary_of_Terms.aspx

DEVLIN, J., \& YEE, P. (2005). rade logistics in developing countries: the case of the Middle East and North Africa. The World Economy, Vol. 28, 435-456.

Everaert, P., Bruggeman, W., Sarens, G., Anderson, S. R., \& Levant, Y. $(2007,2010)$. ost modeling in logistics using time-driven ABC: Experiences from a wholesaler. International Journal of Physical Distribution \& 
Logistics Management, 172-191.

Fulconis F, P. G. (2011). La prestation logistique : origines, enjeux et perspectives. Collection Les Essentiels de la Gestion. Cormelles-le-Royal : Éditions EMS.

Gervais, M., Levant, Y., \& Ducrocq, C. (2010). Time-Driven Activity-Based Costing (TDABC): An Initial Appraisal through a Longitudinal Case Study. . Journal of Applied Management Accounting Research, 1-20.

Gunasekaran, A., \& Sarhadi, M. (1998). Implementation of activity-based costing in manufacturing. Intemational Journal of Production Economics, , 56-57, 231-242.

Helga Pavlic Skender, Alen Host,Melisa Nuhanovic. (2016, October 12). THE ROLE OF LOGISTICS SERVICE PROVIDERS IN INTERNATIONAL TRADE. 16th International Scientific conference Business Logistics in Modern Management, 37.

Homburg. (2005). Using relative profits as an alternative to activity-based costing. nternational Journal of Production Economics, 387-397.

Ivanaj Vera, M.-F. Y. (2006). analyse choice of logistics providers. International Journal of Operations and Production Management, 542-559.

Johnson, H.T., \& Kaplan, R.S. (1993). Contabilidade gerencial: a restauração da relevância da contabilidade nas. . Rio de Janero: Campus, Ed.

Kaplan, R. S., \& Anderson, S. R. (2007). Time-Driven Activity-Based costing. Retrieved from https://hbr.org/2004/11/time-driven-activity-based-costing

Landry, J. (2015). Business Competition Has Not Gotten Fiercer. Retrieved 11 12, 2020, from Harvard Business Review: https://hbr.org/2015/07/business-competition-has-not-gotten-fiercer

M. Michrafy \& T. Roques. (2003). Logistics Service Providers in France-2002 Survey : Actors,Perceptions and Changes in Practices. Supply Chain Forum, 34-52.

Ma, H. (2014). The Study of Cost Accounting in S Company Based On TDABC. International Journal of Mechanical and Industrial Engineering, 1715-1723.

Moutmihi, Mamdouh Tlaty \& Mohamed. (2015). From the logistics function to the logistics service: A literature review. Global Journal of Management and Business Research: A Administration and Management, 8.

Ness, J., \& Cucuza, T. J. (1995). Tapping the full potential of ABC. Harvard Business Review, 130-138.

Paulo Afonso, A. S. (2016). Application of the TDABC Model in the Logistics Process Using Different Capacity Cost Rates. Journal of Industrial Engineering and Management, 1005-1007.

Pawłyszyn, I. (2017). TIME-DRIVEN ACTIVITY BASED COSTING AS A BASIS FOR UNDERTAKING LEAN ACTIVITIES. Scientific Journal of Logistics, 135-149.

Pernot, E. R. (2007). Time-Driven Activity-Based Costing for Inter-Library Services: A Case Study in a University. . The Journal of Academic Librarianship, 551-560.

Pernot, E., Roodhoft, F., \& Van den Abbeele, A. (2007). Time-Driven Activity-Based Costing for inter-library services: A case study in a university. . The Journal of Academic Librarianship, 551-560.

Persson G., V. H. (2001). Growth strategies for logistics service providers: a case study. The International Journal of Logistics Management, 12, 53-64.

Prologis Inc. (2020). Retrieved from prologis.com: https://www.prologis.com/about/resources/what-isprocurement-and-logistics-management

Reynolds, A., Fourie, H., \& Erasmus, L. (2018). A framework for time-driven activity-based costing implementation at small and medium enterprises. The Southern African Journal of Entrepreneurship and Small Business Management, 1-11.

Rinsler, D. W. (2014). outsourcing: the result of global supply chains? In D. W. Rinsler, Global Logistics New directions in supply chain management (p. 513). London, Philadelphia, New Delhi: KoganPage.

Rothery, B. a. (1996). The Truth about Outsourcing. Gower: Aldershot.

Sim, S.-H. H.-H. (1994). Time-based competition: literature review and implications for modelling. International Journal of Operations \&Production Management, Vol. 16, 75-90.

Sohail S., A. N. (2004). The use of third-party logistics services: evidence from a sub-Sahara African nation. International Journal of Logistics: Research and Applications, 7.

Supply Chain Science. (2016, Feb. 14). LLP-Lead Logistics Provider:Are LLPs the future? Retrieved from Supply Chain Science: https://supplychainscience.wordpress.com/2016/02/14/1lp-lead-logistics-providerarellps-the-future/

Sure Destiny . (2018, March 15). Definition of a (4PL) and differences with a (3PL). Retrieved from Sure Destiny : http://www.suredestiny.com/blog-sd/

Tsai, W. a. (2018). Green Production Planning and Control Model with ABC under Industry 4.0 for the Paper Industry. Sustainability, 29-32.

Villarreal. ( 2008).

Wang, Q. Z. (2006). Strategic postures of third-party logistics providers in mainland China. International Journal of Physical Distribution \& Logistics Management, 793-819. 
YOUNG, J. (2019, July 15). procurement. Retrieved from investopedia: https://www.investopedia.com/terms/p/procurement.asp

Zaryab Sheikh, S. R. (2014, 05). The Role of Logistics Service Providers in Supply Chain Performance Management: A comprehensive Literature Review. International Journal of Academic Research in Business and Social Sciences, Vol. 4, 608-613. 